\title{
Loss of NOSI expression in high-grade renal cell carcinoma associated with a shift of $\mathrm{NO}$ signalling
}

\author{
K Renaudin 1,2, MG Denis², G Karam ${ }^{3}$, G Vallette ${ }^{2}$, F Buzelin', CL Laboisse ${ }^{1,2}$ and A Jarry ${ }^{*, 2}$ \\ 'Pathology Department, CHU Hôtel Dieu, 30 Boulevard Jean Monnet, 44093 Nantes Cedex I, France; ${ }^{2}$ INSERM U539, Faculty of Medicine, I Rue \\ Gaston Veil, 44035 Nantes Cedex I, France; ${ }^{3}$ Urology Department, CHU Hôtel Dieu, Place Alexis Ricordeau, 44093 Nantes Cedex I, France
}

In normal human kidney, NOSI and soluble guanylate cyclase (sGC) are expressed in tubular epithelial cells, suggesting a physiological autocrine NO signalling pathway. Therefore, we investigated both NOSI and sGC expressions in benign and malignant renal tumours. In addition, we examined the pattern of protein tyrosine nitration in normal and tumour tissue. NOSI expression and activity were found to be downregulated, correlating with the tumour grade, as shown by immunohistochemistry, quantitative RT PCR analysis, and histochemical detection of the NADPH-diaphorase activity of nitric oxide synthases (NOS). These results show that the autocrine $\mathrm{NO}$ signalling pathway is maintained in benign tumours and lost in malignant tumours. In contrast, sGC expression was maintained in renal tumours whatever the tumour type, a finding showing that tumour cells remain sensitive to the bioregulatory role of exogeneous NO: Finally, the staining pattern of protein tyrosine nitration, assessed by immunohistochemistry, parallelled that of NOSI expression in normal renal parenchyma and benign tumours, supporting the concept that protein nitration was accounted for by NOSI activity. In contrast, in malignant tumours, protein tyrosine nitration was accounted for by the production of reactive nitrogen oxide species by the inflammatory infiltrate. Altogether, these findings argue for a pattern of NO signalling similar in normal kidney and benign renal tumours, whereas it is completely different in malignant renal tumours.

British Journal of Cancer (2004) 90, 2364-2369. doi:I0.1038/sj.bjc.660I809 www.bjcancer.com

Published online II May 2004

(c) 2004 Cancer Research UK

Keywords: NOS; human kidney; renal cell carcinoma; soluble guanylate cyclase; protein nitration; NO signalling

Nitric oxide synthases (NOS) are a family of enzymes that catalyse the synthesis of NO, a gaseous free radical involved in both physiological and pathological mechanisms depending on its concentration, cellular source and microenvironment (Nathan, 1992; Kone, 1997; Michel and Feron, 1997; Alderton et al, 2001). Three isoforms have been described, two 'constitutive', $\mathrm{Ca}^{2+}$-dependent isoforms, that is, NOS1 or neuronal NOS and NOS3 or endothelial NOS, and one 'inducible', $\mathrm{Ca}^{2+}$-independent isoform, NOS2 (for general reviews, see Michel and Feron, 1997; Alderton et al, 2001).

We have recently shown that most tubular epithelial cells along the human nephron strongly express NOS1, as well as soluble guanylate cyclase (sGC), the intracellular target of $\mathrm{NO}^{\circ}$, leading to an autocrine NO signalling pathway in physiological conditions (Jarry et al, 2003). Given that $\mathrm{NO}^{\circ}$ has an important bioregulatory role through its direct effects on sGC or by regulating the electron transport chain in mitochondria (Wink et al, 1996; Wink and Mitchell, 1998), one can wonder whether this autocrine signalling pathway is maintained or not in renal tumours. NOS1 is of particular interest since, besides synthesising $\mathrm{NO}^{\circ}$, it can also produce reactive oxygen species including superoxide ions $\left(\mathrm{O}_{2}^{-}\right)$ and hydrogen peroxide $\left(\mathrm{H}_{2} \mathrm{O}_{2}\right)$ at low L-arginine concentrations (Xia et al, 1996). In addition, the combination of equimolar production of $\mathrm{O}_{2}^{-}$from several sources and $\mathrm{NO}^{*}$ forms peroxynitrite $\left(\mathrm{ONOO}^{-}\right)$, an oxidising and nitrating agent leading to the

*Correspondence: Dr A Jarry; E-mail: ajarry@sante.univ-nantes.fr Revised 6 January 2004; accepted 4 March 2004; published online II May 2004 nitration of protein tyrosine residues limited intracellularly within close proximity of its source (Ischiropoulos et al, 1992; Beckman et al, 1994; Jourd'heuil et al, 2001). Together, these findings strongly suggest that protein tyrosine nitration is a posttranslational modification of proteins associated with NOS1 activity (Williams et al, 1998). This concept is in line with recent findings suggesting that $\mathrm{ONOO}^{-}$via protein tyrosine nitration could have bioregulatory physiological roles, for example, modulation of $\mathrm{Na}+\mathrm{K}+$ ATPase in rat kidney (Zhang et al, 2002). In pathological states, especially in inflammatory conditions, protein tyrosine nitration can result from complex mechanisms involving the formation of $\mathrm{NO}_{2}^{*}$ via the oxidation of circulating nitrite $\mathrm{NO}_{2}^{-}$catalysed by peroxidase or haeme proteins, a process able to target even cells devoid of the endogeneous NO production machinery such as red blood cells (Ischiropoulos, 1998; Wink and Mitchell, 1998, Grzelak et al, 2001).

Several lines of investigation have pointed to a bioregulatory role associated with protein tyrosine nitration such as enzymatic regulation, for example, inactivation of manganese superoxide dismutase (MacMillan-Crow et al, 1996), cell proliferation and apoptosis (Williams et al, 1998; Brito et al, 1999). It is thus important to assess the extent of protein tyrosine nitration in normal and tumour tissues.

In this context, we were prompted to examine in benign and malignant renal tumours several issues, namely (i) the status of NOS1 expression in renal tumours of various grades of malignancy at the protein and mRNA levels; (ii) the persistence or not of an autocrine NO signalling pathway in renal tumours assessed by the 
immunohistochemical detection of sGC; and (iii) the pattern of protein tyrosine nitration in human normal kidney and in renal tumours, assessed by immunohistochemical detection of 3nitrotyrosine. We used red blood cells in order to distinguish protein tyrosine nitration resulting either from an intracellular production of $\mathrm{ONOO}^{-}$(negative staining of red blood cells) or from the production by the inflammatory infiltrate of reactive nitrogen species able to act at distance from their source (positive staining of red blood cells).

\section{MATERIALS AND METHODS}

\section{Tissue specimens}

Tumour tissue and normal tissue at distance from the tumour were collected from 32 patients undergoing nephrectomy for oncocytoma (six cases), chromophobe renal cell carcinoma (RCC) (four cases) and clear cell RCC (22 cases: five cases Führman grade I; seven cases Führman grade II; seven cases Führman grade III; three cases Führman grade IV). For each case, samples of tumour and normal tissue were snap frozen and stored in liquid nitrogen, and also fixed in formalin and embedded in paraffin. These samples were collected according to the guidelines of the French Ethics Committee for Research on Human Tissues.

\section{Immunohistochemistry}

Immunohistochemistry was performed on $5 \mu \mathrm{m}$ formalin-fixed paraffin sections of different renal tumours with the polyclonal Nterminus NOS1, the sCG and the 3-nitrotyrosine antibodies, and on $5 \mu \mathrm{m}$ acetone-fixed cryostat sections for staining with the monoclonal C-terminus NOS1, the NOS2 and the NOS3 antibodies. The specificity and conditions of use of primary antibodies directed to NOS isoforms are listed in Table 1. First, endogenous biotin was blocked using a sequential avidin-biotin treatment (Biotin blocking system, Dako, Trappes, France). Then, immunohistochemistry was performed using a streptavidin-biotin method (Histostain Plus kit, LAB-SA detection system, Zymed, Cliniscience, Montrouge, France), according to the manufacturer's instructions. Aminoethyl carbazol (AEC) or diaminobenzidine (DAB) were used as chromogens. The sections were slightly counterstained with haematoxylin and mounted. Negative controls were performed by omitting the first antibody. To verify the specificity for nitrotyrosine, the antinitrotyrosine antibody was pretreated for at least $1 \mathrm{~h}$ at room temperature with 3-nitrotyrosine (Sigma, $10 \mathrm{~mm}$ solution, $\mathrm{pH}$ 7.4) prior to incubation on tissue sections. Immunohistochemical staining was assessed by two independent observers (KR, AJ) including a pathologist (KR).

\section{NADPH-diaphorase histochemistry}

In total, $5 \mu \mathrm{m}$ cryostat sections were fixed for $15 \mathrm{~min}$ in a freshly made paraformaldehyde solution $\left(4 \% \mathrm{wv}^{-1}\right.$ in $\left.\mathrm{PBS}\right)$ and then washed four times in PBS. The NADPH-diaphorase (NADPH-d) activity of NOS, which is paraformaldehyde-resistant, was demonstrated by enzymatic reduction of nitroblue tetrazolium in the presence of NADPH, as previously described (Weinberg et al, 1996). Briefly, slides were incubated in $1 \times$ PBS containing $1 \mathrm{mg} \mathrm{ml}^{-1}$ NADPH (Roche Molecular Biochemicals, Meylan, France) and $0.4 \mathrm{mg} \mathrm{ml}^{-1} \mathrm{NBT}$ (Roche Molecular Biochemicals) for $30 \mathrm{~min}$ at $37^{\circ} \mathrm{C}$, washed in PBS, dehydrated and mounted without any counterstaining. NADPH was omitted in negative controls.

\section{Quantitative RT - PCR analysis of NOS1 expression}

Total RNA was extracted from four cases of Führman III RCC and normal renal parenchyma from the same patients using the GenElute Mammalian Total RNA kit (Sigma, Saint-Quentin Fallavier, France) and the Fast Prep cell disrupter (Bio 101, QBIOgene, Illkirch, France). RNA ( $5 \mu \mathrm{g}$ ) was denaturated at $72^{\circ} \mathrm{C}$ for $3 \mathrm{~min}$ and then reverse transcribed for $60 \mathrm{~min}$ at $42^{\circ} \mathrm{C}$ in a $20 \mu \mathrm{l}$ reaction volume (50 mM Tris- $\mathrm{HCl} \mathrm{pH} 8.3,75 \mathrm{~mm} \mathrm{KCl,} 3 \mathrm{~mm} \mathrm{MgCl}$, $10 \mathrm{~mm}$ DTT) containing $0.5 \mu \mathrm{g}$ of random hexamers (Promega, Charbonnières, France), dNTPs (1 mM each), RNasin (50 U) and $\mathrm{RnaseH}^{-}$MMLV reverse transcriptase (200 U).

The amplification conditions of the NOS1 and $\beta$-actin templates were optimised for the Rotorgene 2000 instrument (Ozyme, Saint Quentin en Yvelines, France). PCR amplifications were performed using Titanium Taq DNA polymerase (Clontech, Ozyme). The reaction mixture contained $2 \mu \mathrm{l}$ of the supplied $10 \times$ Titanium Taq PCR buffer (containing magnesium chloride), $2 \mu \mathrm{l}$ of a $1 / 1000$ dilution of SYBR Green I (Roche Molecular Biochemicals), $1 \mu \mathrm{l}$ of each primer $(0.4 \mu \mathrm{m}$ each), $0.4 \mu \mathrm{l}$ of Titanium Taq DNA polymerase, $0.5 \mu \mathrm{l}$ of dNTPs ( $10 \mathrm{~mm}$ each) and PCR-grade water to a volume of $15 \mu \mathrm{l}$. Microtubes $(0.2 \mathrm{ml})$ were loaded with $15 \mu \mathrm{l}$ of this master mix and $5 \mu \mathrm{l}$ of the template (cDNA diluted 1/50) and the run was initiated. The cycling conditions were as follows:

Table I Antibodies used for immunohistochemistry

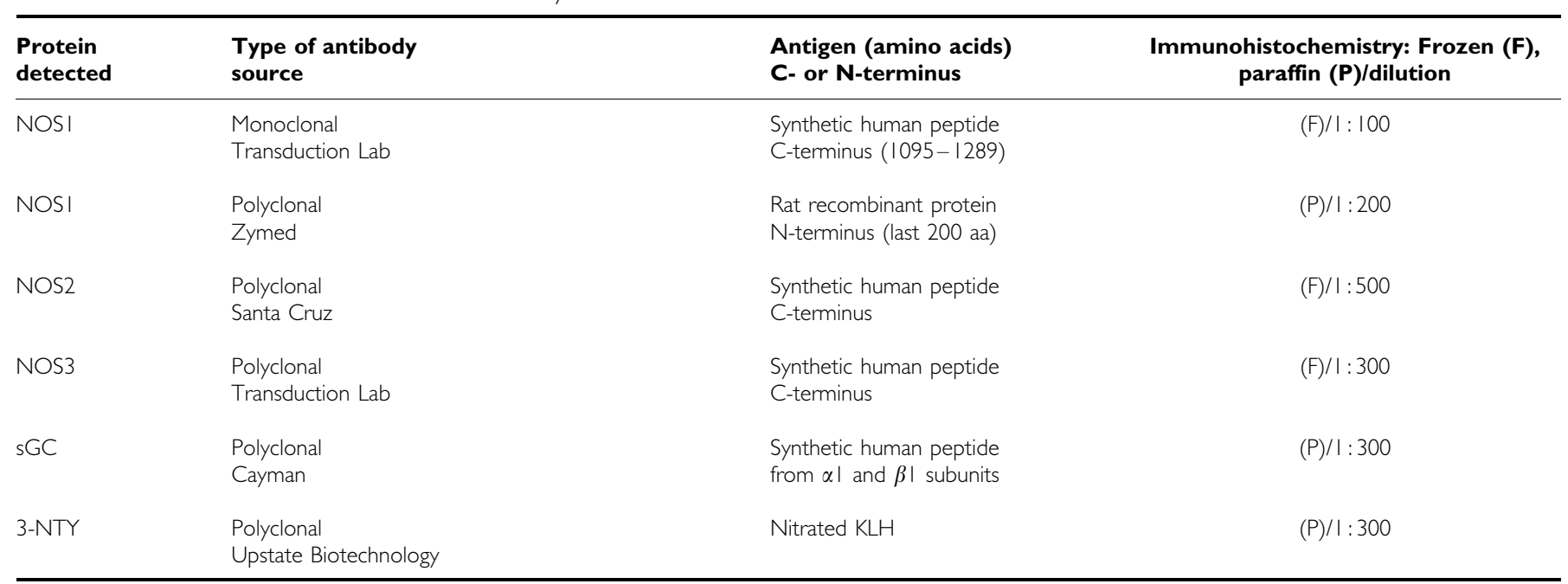


denaturation for $5 \mathrm{~min}$ at $95^{\circ} \mathrm{C}$; amplification for 35 cycles, with denaturation for $5 \mathrm{~s}$ at $95^{\circ} \mathrm{C}$, annealing for $10 \mathrm{~s}$ at $63^{\circ} \mathrm{C}$ and extension for $20 \mathrm{~s}$ at $72^{\circ} \mathrm{C}$. To exclude primer-dimer artifacts, fluorescence was not measured at the end of the extension step, but a separate detection step was added $(15 \mathrm{~s})$ at a temperature $\left(88^{\circ} \mathrm{C}\right)$ above the melting point of primer-dimers and below the melting point of the specific PCR product $\left(92^{\circ} \mathrm{C}\right)$.

Primers NOS1 sense $\left(5^{\prime}-\mathrm{TCT}\right.$ CCT CCT ACT CTG ACT CC- $\left.3^{\prime}\right)$ and NOS1 antisense ( $5^{\prime}$-TTG TGG ACA TTG GAT AGA CC- $3^{\prime}$ ) were designed from the sequence of the human NOS1 cDNA (accession number NM-000620). They were selected for binding to separate exons (exon 17 and exon 20, respectively) to avoid false positive results arising from amplification of contaminating genomic DNA.

After completion of the cycling process, samples were subjected to a temperature ramp from 63 to $99^{\circ} \mathrm{C}$, with continuous fluorescence monitoring for melting curve analysis. For each amplification, apart from primer-dimers, a single narrow peak was obtained at the expected melting temperature $\left(92^{\circ} \mathrm{C}\right)$, indicating specific amplification without significant by-products.

An external standard curve was generated with serial five-fold dilutions of cDNA $(1: 20,1: 100$ and $1: 500)$ prepared from normal kidney RNA. The reference curve was constructed by plotting the relative amounts of these dilutions $v s$ the corresponding $\mathrm{Ct}$ (threshold cycle) values. The correlation coefficient of these curves was always greater than 0.99 . The amount of NOS1 transcript was calculated from these standard curves using the RotorGene software. A relative unit of 100 was assigned for the standard cDNA diluted 1/500. Samples were tested in triplicate and the average values were used for quantification.

For each sample, the relative amount of human $\beta$-actin cDNA was determined, as described for NOS 1 with primers $5^{\prime}$-CCT TCC TGG GCA TGG AGT CCT G-3' (actin sense) and 5'-GGA GCA ATG ATC TTG ATC TTC- $3^{\prime}$ (actin antisense). The ratio between the relative amount of NOS1 and $\beta$-actin was then calculated to compensate for variations in quantity or quality of starting mRNA as well as for differences in reverse transcriptase efficiency.

\section{RESULTS}

Downregulation of NOS1 expression in high-grade clear cell RCC detected by immunohistochemistry, associated with a loss of the NADPH-diaphorase activity of NOS

We assessed the expression of NOS1 in tumour samples by using an antibody directed to the C-terminus part of NOS1 on cryostat sections. To confirm the staining pattern, we used another antibody directed to the N-terminus part of NOS1, on paraffin sections of a few cases of each type of tumour. The overall staining pattern was found identical with both antibodies (Table 2). NOS1 was expressed in tumour cells of oncocytomas, chromophobe RCC and in few cells of Fürhman I and II clear cell RCC. Conversely, Fürhman III and IV clear cell RCC never expressed NOS1 (Figure 1).

We then confirmed that the downregulation of NOS1 immunoreactivity was in parallel with a loss of the NOS reductase activity. The results of the histochemical detection of NOS reductase activity by NADPH-d histochemistry, performed on paraformaldehyde-fixed cryostat sections of the different renal tumours, are summarised in Table 2. A high NADPH-d activity was detected in tumour cells of benign tumours and tumours of low malignancy, that is, oncocytoma and chromophobe RCC, respectively. A lower and heterogeneous staining pattern was observed in tumour cells of low-grade clear cell RCC (Fürhman grade I and rarely grade II). No activity was detected in Fürhman grade III or IV clear cell RCC. In all type of tumours, endothelial cells displayed a NADPH-d activity.
The downregulation of NOS1 expression in high-grade clear cell RCC is correlated with a dramatic decrease in NOS1 mRNA levels

In order to determine whether the lack of NOS1 expression was correlated with its mRNA level, the amount of NOS1 mRNA was measured by real-time quantitative RT - PCR in four specimens of grade III clear cell RCC and the corresponding normal tissue. As shown in Figure 2, the level of NOS1 mRNAs relative to $\beta$-actin levels was undetectable in the tumour tissue of grade III clear cell RCC, whereas high NOS1 levels were found in the corresponding normal renal tissue.

\section{The downregulation of NOS1 expression in high-grade clear cell RCC is not associated with an upregulation of other NOS isoforms expression in tumour cells}

To further confirm that the loss of NOS1 expression was not associated with an upregulation of other NOS isoforms, we assessed both NOS2 and NOS3 expression by immunohistochemistry in the renal tumours. In our study we did not find any NOS2 expression in tumour cells whatever the tumour type or grade. Only a few NOS2-positive inflammatory cells were noted within the stromal reaction and served as an internal positive control. NOS3 was never found in tumour cells, but, as expected from the NADPH-d assay, endothelial cells were stained with the NOS3 antibody.

The downregulation of NOS1 expression in high-grade clear cell RCC is not associated with a loss of SGC, the physiological intracellular target of $\mathrm{NO}^{\circ}$

We assessed by immunohistochemistry the expression of sGC in two cases of each tumour type. The sGC was expressed in tumour cells of oncocytomas, chromophobe RCC and clear cell RCC whatever the Fürhman grade (not shown).

\section{Pattern of protein nitration in renal tumours compared} with normal renal parenchyma

As protein tyrosine nitration is a post-translational modification of many proteins that can be accounted for by several mechanisms that is, formation of $\mathrm{ONOO}^{-}$or other reactive nitrogen species $\left(\mathrm{NO}_{2}^{*}, \mathrm{NO}_{2} \mathrm{Cl}\right)$ (Ischiropoulos, 1998; Wink and Mitchell, 1998), it was important to design a protocol to distinguish between these different processes. Interestingly, as the chemistry of $\mathrm{ONOO}^{-}$is

Table 2 NADPH-diaphorase activity of NOS and NOSI expression in renal tumours

\begin{tabular}{lccc}
\hline & \multicolumn{2}{c}{$\begin{array}{c}\text { NOSI } \\
\text { immunohistochemistry }\end{array}$} & \\
\cline { 2 - 3 } & $\begin{array}{l}\text { Cryostat } \\
\text { sections } \\
(\boldsymbol{n}=\mathbf{2 9 )}\end{array}$ & $\begin{array}{c}\text { Paraffin } \\
\text { sections } \\
(\mathbf{n}=\mathbf{9 )}\end{array}$ & $\begin{array}{c}\text { NADPH-d } \\
\text { activity }(\boldsymbol{n}=\mathbf{2 9})\end{array}$ \\
Tumour type & $5 / 5$ & $2 / 2$ & $5 / 5$ \\
\hline Oncocytoma & $2 / 2$ & $2 / 2$ & $2 / 2$ \\
Chromophobe RCC & $5 / 5$ & $1 / 1$ & $5 / 5$ \\
Clear cell RCC & $1 / 7$ & $1 / 2$ & $1 / 7$ \\
Fürhman I & $0 / 7$ & $0 / 1$ & $0 / 7$ \\
Fürhman II & $0 / 3$ & $0 / 1$ & $0 / 3$ \\
Fürhman III & Fürhman IV & & \\
\hline
\end{tabular}

NADPH-diaphorase histochemistry was performed on cyrostat sections, and NOSI immunohistochemistry on cryostat or paraffin sections depending on the antibody used (see Material and Methods). The numbers indicated in the table represent the number of positive tumours over the total number of tumours studied. 
NOS1
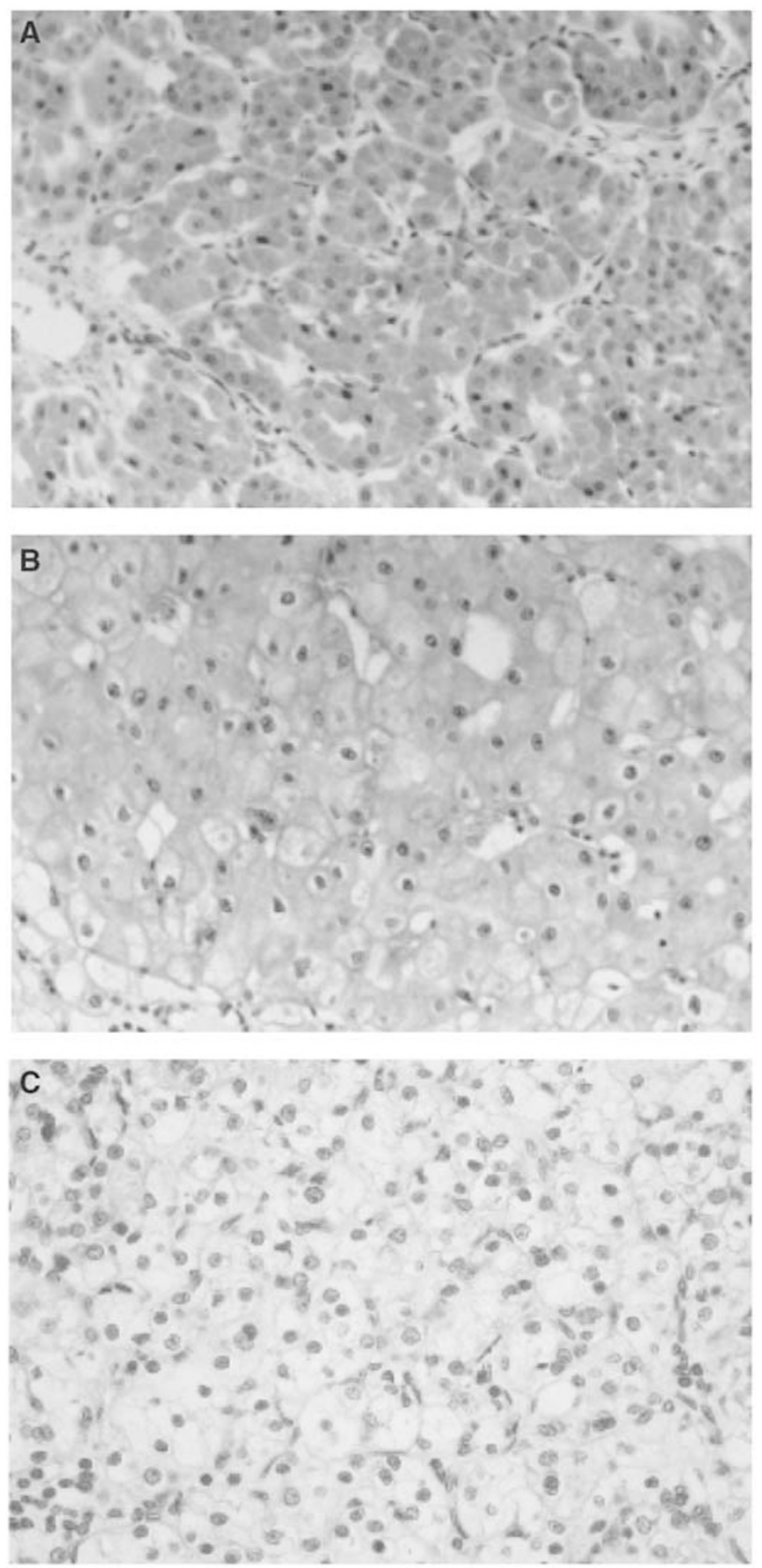

Figure I Correlation of NOSI expression in human renal tumours with the tumour grade. Immunolocalisation of NOSI on paraffin sections of a representative case of benign tumour (oncocytoma: A), low-malignant carcinoma (chromophobe RCC: B) and grade III clear cell RCC (C). Tumour cells were strongly labelled with the NOSI antibody in the oncocytoma and chromophobe cell carcinoma, whereas they were negative in the high-grade RCC (original magnification $\times 200$ ).

limited within close proximity of its source, only proteins located proximally to its site of generation can be nitrated. In contrast, other nitrating species, including the oxidation of $\mathrm{NO}_{2}^{-}$into $\mathrm{NO}_{2}^{-}$in the presence of myeloperoxidase or other haeme proteins (Grzelak et al, 2001) as well as the formation of $\mathrm{NO}_{2} \mathrm{Cl}$, are known to have a long range of action and nitrate proteins at distance from their production site, that is, inflammatory cells (Wink and Mitchell,

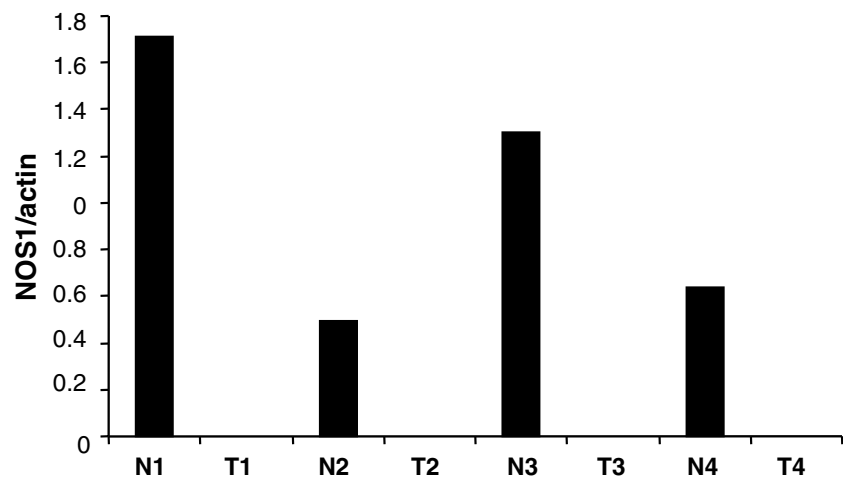

Figure 2 Quantitative analysis of NOSI mRNA in grade III clear cell RCC. Total RNAs were extracted from the tumour of four patients undergoing surgery for grade III clear cell RCC (TI - T4) and also from the corresponding normal renal parenchyma $(\mathrm{NI}-\mathrm{N} 4)$ taken at distance from the tumour, reversed transcribed and submitted to real time PCR as described in Material and Methods. Amounts of NOSI amplification products were normalised to $\beta$-actin. In the four cases, NOSI mRNAs were beyond the limit of detection in the tumours whereas they were always present in the corresponding normal renal parenchyma.

Table 3 Immunostaining pattern of protein nitration compared with that of NOSI in the normal human renal parenchyma

\begin{tabular}{lcc}
\hline & \multicolumn{2}{c}{ Immunostaining pattern } \\
\cline { 2 - 3 } Intrarenal distribution & 3-nitrotyrosine & NOS I $^{\mathbf{a}}$ \\
\hline Glomerulus & & \\
Mesangial cells & \pm & - \\
Parietal cells & \pm & - \\
Podocytes & + & \pm \\
Proximal tubules & + & + \\
Distal tubules & + & + \\
Henle's loops & + & + \\
Collecting ducts & - & + \\
Red blood cells & + & - \\
\hline
\end{tabular}

3-Nitrotyrosine immunohistochemistry was performed on paraffin section of three cases of normal renal parenchyma. $-=$ no staining; $\pm=$ heterogeneous positive staining; $+=$ homogeneous positive staining. ${ }^{a} \mathrm{NOS}$ I staining pattern already fully described in normal kidney in a previous paper (Jarry et al, 2003).

1998; Espey et al, 2002). Since red blood cells are devoid of NOS, the assessment of red blood cells nitration can thus be considered as a simple index of the production in the cellular environment of reactive nitrogen species with a long range of action.

We assessed the pattern of protein nitration by immunohistochemistry in three cases of normal parenchyma and in three cases of each tumour type. In normal renal parenchyma the overall staining pattern was identical to the NOS1 expression pattern (Table 3 and Figure 3A), with no red blood cell nitration. In benign tumours (i.e. oncocytoma), the staining pattern of nitration was similar to the one of NOS1 with a strong, granular and homogeneous staining of tumour cells, and without any staining of red blood cells in the absence of inflammatory infiltrate (Table 4 and Figure 3B). In contrast, in malignant tumours (i.e. chromophobe RCC and clear cell RCC), surrounded by an important inflammatory infiltrate, the pattern of protein nitration was highly heterogeneous, with some parts of the tumour strongly stained and others devoid of any staining. In addition, there was an intense staining of red blood cells in vessels within or near the tumour (Table 4 and Figure 3C). 


\section{3-Nitrotyrosine}
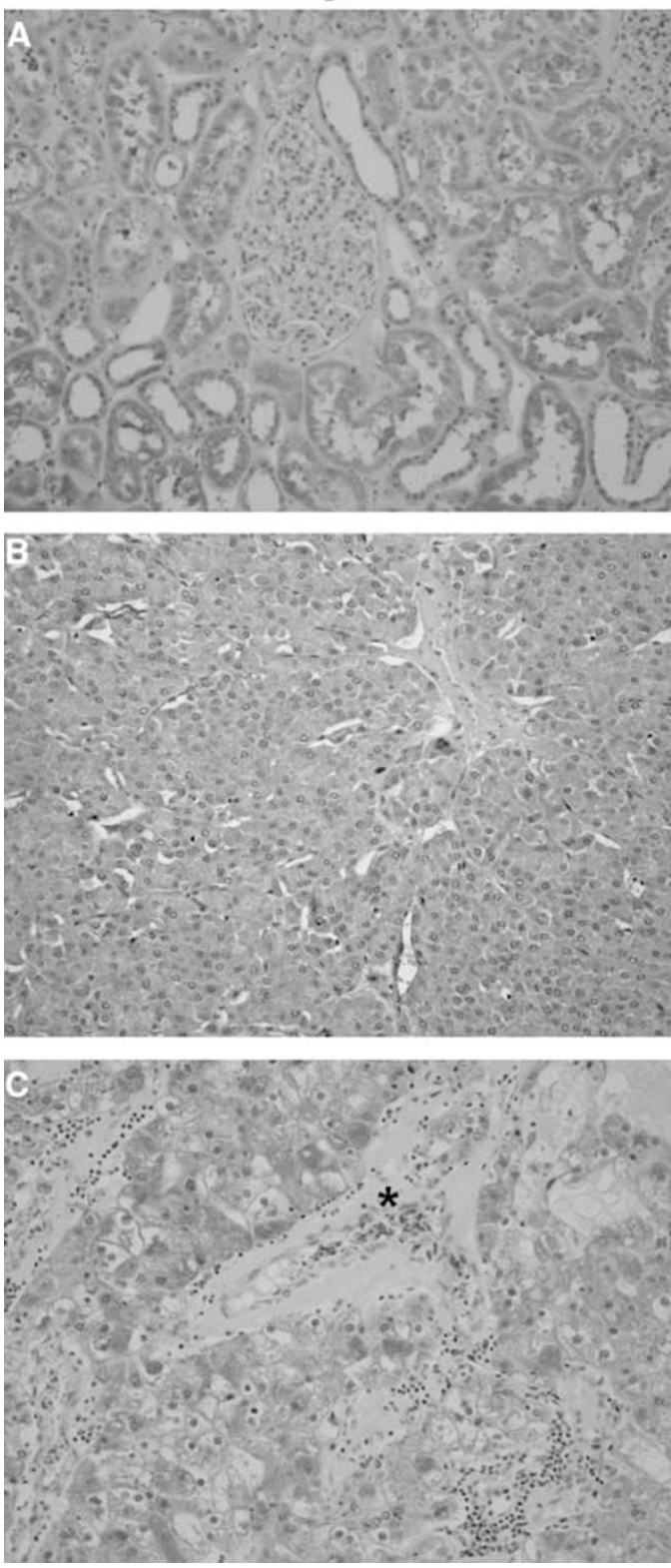

Figure 3 Changes in the immunostaining pattern of protein tyrosine nitration between normal human kidney/benign tumour and RCC. Immunodetection of 3-nitrotyrosine on paraffin sections. (A) In normal renal parenchyma, most of the tubular epithelial cells along the nephron were labelled, with a variable staining intensity. In glomeruli, some of the podocytes and parietal cells scored positive. Red blood cells were not labelled. (B) In oncocytoma, a strong, granular and homogeneous staining of tumour cells was noted. Red blood cells were not labelled, and there was no inflammatory infiltrate. (C) In contrast, in malignant tumours (a case of grade III clear cell RCC is shown), the pattern of protein tyrosine nitration was heterogeneous. Red blood cells (*) were strongly stained and an inflammatory infiltrate was present (original magnification $\times 200$ ).

\section{DISCUSSION}

Our results show a modulation of NOS1 expression correlating with the pathological grading and the malignant potential of renal tumours. These results support and extend previous findings showing that $\mathrm{Ca}^{2+}$-dependent NOS activity, measured by
Table 4 Pattern of protein nitration in renal tumours: correlation with the nitration of red blood cells and the degree of the inflammatory infiltrate

\begin{tabular}{|c|c|c|c|}
\hline \multirow[b]{2}{*}{ Tumour type } & \multicolumn{2}{|c|}{$\begin{array}{c}\text { 3-Nitrotyrosine } \\
\text { immunohistochemistry }\end{array}$} & \multirow{2}{*}{$\begin{array}{c}\text { Inflammatory } \\
\text { infiltrate }\end{array}$} \\
\hline & Tumour cells & Red blood cells & \\
\hline Oncocytoma & Homogeneous & - & - \\
\hline $\begin{array}{l}\text { Chromophobe RCC } \\
\text { Clear cell RCC }\end{array}$ & Heterogeneous & + & + \\
\hline Fürhman I & Heterogeneous & + & ++ \\
\hline Fürhman ॥ & Heterogeneous & + & +++ \\
\hline Fürhman III & Heterogeneous & + & +++ \\
\hline Fürhman IV & Heterogeneous & + & +++ \\
\hline
\end{tabular}

3-Nitrotyrosine immunohistochemistry was performed on paraffin sections of three cases of each tumour type. The immunostaining of tumour cells was referred to as 'homogeneous' when a majority of cells was stained with the same intensity and as 'heterogeneous' when some parts of the tumour were stained and others devoid of any staining. Immunostaining of red blood cells: $(-)$ denotes absent and $(+)$ denotes majority of red blood cells stained. Semiquantitative evaluation of the inflammatory infiltrate: $(-)$ means absence of infiltrate; $(+)$ denotes a mild infiltrate, $(++)$ a moderate infiltrate and $(+++)$ an abundant infiltrate.

L-arginine to L-citrulline conversion assay, was significantly lower in RCCs than in normal renal parenchyma and inversely correlated with the tumour grade according to Führman's classification (Jansson et al, 1998). In this study the calcium-independent inducible NOS activity was undetectable in RCC (Jansson et al, 1998). Similarly, in our study, NOS2 was never detected by immunohistochemistry in all the tumours tested, thus suggesting that the loss of NOS1 expression was not counterbalanced by induction of NOS2 expression in tumour cells. The downregulation of NOS1 expression in high-grade clear cell RCC is associated with the absence of NOS1 mRNA, as shown by real-time RT-PCR. Numerous splicing variants of the NOS1 gene have been described (Forstermann et al, 1998). Most of them differ in their $5^{\prime}$ end. One cannot exclude that high-grade clear cell RCC tumour cells express a specific splicing variant of NOS1 mRNA, which would not have been detected in our experimental conditions. But this is unlikely, since the PCR primers were designed to span a large central area of the transcript. Furthermore, we used on purpose two antibodies specific for the N- and C-terminus part of NOS1, which should have allowed us to detect a truncated protein. Therefore, we can conclude that the absence of detectable NOS1 mRNA is probably due to a significant decrease in NOS1 gene transcription or/and in NOS1 mRNA stability, although a deletion or a mutation in the NOS1 gene cannot yet be excluded. Further investigations are needed to elucidate this issue.

Another interesting finding of our study is that the loss of NOS1 expression in high-grade RCC is not associated with a loss of sGC expression. This result leads to two conclusions: (i) the autocrine signalling pathway of NO previously observed in normal human tubular epithelial cells (Jarry et al, 2003) is maintained in benign tumours and low malignant potential RCC but not in high-grade clear cell RCC, and (ii) the persistence of sGC expression in all tumour types implies that tumour cells remain sensitive to the bioregulatory roles of exogeneous NO.

The third major finding of this study concerns the pattern of protein tyrosine nitration, which is identical in normal kidney and in benign renal tumours, but completely different in malignant tumours. Nitration is a covalent modification of the tyrosine residues of some proteins with activating or inhibitory activities that could be involved in physiological conditions as well as in pathological states such as inflammatory processes and tumours 
(Aulak et al, 2001; Greenacre and Ischiropoulos 2001; Ehsan et al, 2002; Ischiropoulos, 2003; Schopfer et al, 2003). Nitration process can result from several mechanisms, that is, intracellular action of $\mathrm{ONOO}^{-}$and long-range action of other reactive nitrogen species produced by inflammatory cells. The most well-known mechanism of protein nitration is the $\mathrm{ONOO}^{-}$pathway, resulting from the reaction of equimolar $\mathrm{NO}^{-}$and $\mathrm{O}_{2}^{-}$, a phenomenon restricted to an organelle or cellular compartment such as mitochondria (Radi et al, 2002; Ghafourifar and Colton, 2003). Our observation of a granular staining pattern with the antinitrotyrosine antibody, identical to that of NOS1, in tubular epithelial cells of normal renal parenchyma and in oncocytoma, is in line with this concept of $\mathrm{ONOO}^{-}$chemistry limited to close proximity of its source. In addition, we can rule out the involvement of long-range acting nitrogen species since red blood cells are devoid of any staining in normal renal tissue and in oncocytoma. In malignant tumours containing an important inflammatory infiltrate, the interpretation of protein nitration pattern is more complex. Indeed, other nitrating species known to have a long range of action are produced by inflammatory cells and result from the oxidation of circulating nitrite $\mathrm{NO}_{2}^{-}$into $\mathrm{NO}_{2}^{-}$, a reaction catalysed by

\section{REFERENCES}

Alderton WK, Cooper CE, Knowles RG (2001) Nitric oxide synthases: structure, function and inhibition. Biochem J 357: $593-615$

Aulak KS, Miyagi M, Yan L, West KA, Massillon D, Crabb JW, Stuehr DJ (2001) Proteomic method identifies proteins nitrated in vivo during inflammatory challenge. Proc Natl Acad Sci USA 98: 12056-12061

Beckman JS, Chen J, Ischiropoulos H, Crow JP (1994) Oxidative chemistry of peroxynitrite. Methods Enzymol 233: 229-240

Bian K, Gao Z, Weisbrodt N, Murad F (2003) The nature of heme/ iron-induced protein tyrosine nitration. Proc Natl Acad Sci USA 100: $5712-5717$

Brito C, Naviliat M, Tiscornia AC, Vuillier F, Gualco G, Dighiero G, Radi R, Cayota AM (1999) Peroxynitrite inhibits T lymphocyte activation and proliferation by promoting impairment of tyrosine phosphorylation and peroxynitrite-driven apoptotic death. J Immunol 162: 3356-3366

Ehsan A, Sommer F, Schmidt A, Klotz T, Koslowski J, Niggemann S, Jacobs G, Engelmann U, Addicks K, Bloch W (2002) Nitric oxide pathways in human bladder carcinoma. The distribution of nitric oxide synthases, soluble guanylyl cyclase, cyclic guanosine monophosphate, and nitrotyrosine. Cancer 95: 2293-2301

Espey MG, Xavier S, Thomas DD, Miranda KM, Wink DA (2002) Direct real-time evaluation of nitration with green fluorescent protein in solution and within human cells reveals the impact of nitrogen dioxide $v s$ peroxynitrite mechanisms. Proc Natl Acad Sci USA 99: 3481 - 3486

Forstermann U, Boissel JP, Kleinert H (1998) Expressional control of the 'constitutive' isoforms of nitric oxide synthase (NOS I and NOS III). FASEB J 12: $773-790$

Ghafourifar P, Colton CA (2003) Compartmentalized nitrosation and nitration in mitochondria. Antioxid Redox Signal 5: 349-354

Greenacre SA, Ischiropoulos H (2001) Tyrosine nitration: localisation, quantification, consequences for protein function and signal transduction. Free Radical Res 34: $541-581$

Grzelak A, Balcerczyk A, Mateja A, Bartosz G (2001) Hemoglobin can nitrate itself and other proteins. Biochim Biophys Acta 1528: $97-100$

Ischiropoulos H (1998) Biological tyrosine nitration: a pathophysiological function of nitric oxide and reactive oxygen species. Arch Biochem Biophys 356: $1-11$

Ischiropoulos H (2003) Biological selectivity and functional aspects of protein tyrosine nitration. Biochem Biophys Res Commun 305: 776-783

Ischiropoulos H, Zhu L, Chen J, Tsai M, Martin JC, Smith CD, Beckman JS (1992) Peroxynitrite-mediated tyrosine nitration catalyzed by superoxide dismutase. Arch Biochem Biophys 298: 431 - 437

Jansson OT, Morcos E, Brundin L, Bergerheim US, Adolfsson J, Wiklund NP (1998) Nitric oxide synthase activity in human renal cell carcinoma. J Urol 160: $556-560$ myeloperoxidase or other haeme proteins in the presence of $\mathrm{H}_{2} \mathrm{O}_{2}$ (Wink and Mitchell, 1998). In addition, the $\mathrm{Cl}^{-}$transfer from $\mathrm{HOCl}$ to $\mathrm{NO}_{2}^{-}$generates $\mathrm{NO}_{2} \mathrm{Cl}$, a nitrating agent (Bian et al, 2003). Since we noticed a downregulation of NOS1 expression in most malignant renal tumours, we can suggest that the reactive nitrogen species released by the inflammatory infiltrate are responsible for the heterogeneous nitrated staining pattern observed in these malignant tumours. This interpretation was strongly supported by the staining of red blood cells, a cell type devoid of any endogeneous source of NO.

In conclusion, our study helped decipher the pattern of NO signalling in renal tumours of different grades compared with that of normal renal parenchyma. The bioregulatory activity of NO is similar in benign tumours and in normal kidney, whereas there is a shift of NO signalling in high-grade malignant tumours, with a loss of endogeneous NO synthesis, but the maintenance of sGC, the receptor for exogeneous NO. The demonstration of nitrated proteins in renal tumours implies that exogeneous NO, especially reactive nitrogen species produced by inflammatory cells, have an impact on cancer cells, whose biological significance remain to be determined.

Jarry A, Renaudin K, Denis M, Robard M, Buffin-Meyer B, Karam G, Paris H, Laboisse CL, Vallette G (2003) Expression of NOS1 and soluble guanylyl cyclase by human kidney epithelial cells. Morphological evidence for an autocrine/paracrine action of NO. Kidney Int 64: $170-180$

Jourd'heuil D, Jourd'heuil FL, Kutchukian PS, Musah RA, Wink DA, Grisham MB (2001) Reaction of superoxide and nitric oxide with peroxynitrite. Implications for peroxynitrite-mediated oxidation reactions in vivo. J Biol Chem 276: 28799-28805

Kone BC (1997) Nitric oxide in renal health and disease. Am J Kidney Dis 30: $311-333$

MacMillan-Crow LA, Crow JP, Kerby JD, Beckman JS, Thompson JA (1996) Nitration and inactivation of manganese superoxide dismutase in chronic rejection of human renal allografts. Proc Natl Acad Sci USA 93: $11853-11858$

Michel T, Feron O (1997) Nitric oxide synthases: which, where, how, and why? J Clin Invest 100: $2146-2152$

Nathan C (1992) Nitric oxide as a secretory product of mammalian cells. FASEB J 6: 3051 - 3064

Radi R, Cassina A, Hodara R, Quijano C, Castro L (2002) Peroxynitrite reactions and formation in mitochondria. Free Radical Biol Med 33: $1451-1464$

Schopfer FJ, Baker PR, Freeman BA (2003) NO-dependent protein nitration: a cell signaling event or an oxidative inflammatory response? Trends Biochem Sci 28: 646-654

Weinberg RJ, Valtschanoff JG, Schmidt HHW (1996) The NADPH diaphorase histochemical stain. In Methods in Nitric Oxide Research, Feelisch M, Stamler JS (eds). pp 237 - 248. Chichester: John Wiley \& Sons Williams MS, Noguchi S, Henkart PA, Osawa Y (1998) Nitric oxide synthase plays a signaling role in TCR-triggered apoptotic death. J Immunol 161: $6526-6531$

Wink DA, Grisham MB, Mitchell JB, Ford PC (1996) Direct and indirect effects of nitric oxide in chemical reactions relevant to biology. Methods Enzymol 268: $12-31$

Wink DA, Mitchell JB (1998) Chemical biology of nitric oxide: Insights into regulatory, cytotoxic, and cytoprotective mechanisms of nitric oxide. Free Radical Biol Med 25: $434-456$

Xia Y, Dawson VL, Dawson TM, Snyder SH, Zweier JL (1996) Nitric oxide synthase generates superoxide and nitric oxide in arginine-depleted cells leading to peroxynitrite-mediated cellular injury. Proc Natl Acad Sci USA 93: $6770-6774$

Zhang C, Imam SZ, Ali SF, Mayeux PR (2002) Peroxynitrite and the regulation of $\mathrm{Na}(+), \mathrm{K}(+)$-ATPase activity by angiotensin II in the rat proximal tubule. Nitric Oxide 7: $30-35$ 